Article Type: Article

Co-author email address is: Jan.Orbie@UGent.be

\title{
Ignoring the Elephant in the Room? Assessing the impact of the European Union on the Development Assistance Committee's role in international development.
}

\author{
Dr. Joren Verschaeve and Prof. dr. Jan Orbie ${ }^{1}$
}

\begin{abstract}
This article studies the impact of the European Union (EU) on the Development Assistance Committee (DAC) of the Organisation for Economic Co-operation and Development (OECD). While literature thus far focused on the external challenges for the DAC's role in international development, this study argues that the EU should be taken into account as well. By focusing on the cases of policy coherence for development and the concessionality of ODA loans, we show that the EU poses a structural challenge for the DAC's role in international development given the strong overlap in membership between both institutions and the Union's changing nature as a development actor.
\end{abstract}

Keywords: OECD, DAC, EU, development cooperation, policy coherence for development, official development assistance.

\section{Introduction}

For more than fifty years now, the Development Assistance Committee (DAC) of the Organisation for Economic Co-operation and Development (OECD) has grouped the world's main donors ${ }^{2}$, serving as a forum for dialogue, coordination and international consensus

\footnotetext{
${ }^{1}$ Both at Centre for EU Studies, Ghent University.

${ }^{2}$ The DAC is composed out of 30 members: Australia, Austria, Belgium, Canada, Czech Republic, Denmark, European Union, Finland, France, Germany, Greece, Hungary, Iceland, Ireland, Italy, Japan, This article has been accepted for publication and undergone full peer review but has not been through the copyediting, typesetting, pagination and proofreading process, which may lead to differences between this version and the Version of Record. Please cite this article as doi: 10.1111/dpr.12216

This article is protected by copyright. All rights reserved.
} 
building. Through its role in defining and monitoring global development standards, it has been influential in defining what we today see as development cooperation. For example, the concepts of official development assistance (ODA), policy coherence for development (PCD) or untied aid all find their origins in its work (Eyben, 2013; Manning, 2008; Masujima, 2004). Furthermore, also its work on establishing the Millennium Development Goals - most notably through its influential report 'Shaping the $21^{\text {st }}$ century' (1996) - and its efforts on aid effectiveness - for example, the Paris Declaration on Aid Effectiveness (2005) - had a strong impact on the way in which the delivery of aid is currently structured (Kim \& Lightfoot, 2011; Manning, 2008; Ruckert, 2008). Finally, when it comes to measuring resource flows to developing countries, the DAC is a global quasi-legislative body, defining, monitoring and reporting ODA from both its members and non-members since the 1960s (Hynes \& Scott, 2013; Verschaeve \& Orbie, 2016a).

In recent years, however, the DAC's role in international development cooperation has become increasingly challenged. Indeed, the changing development landscape - i.e. the proliferation of new development actors and ideas - calls into question the legitimacy of the existing aid architecture, including the role of the DAC in governing development issues (Besada \& Kindornay, 2013; Kragelund, 2011; McEwan \& Mawdsley, 2012; Woods, 2008b). This sparked much debate among scholars and development practitioners on whether or not the DAC will remain a relevant forum for global aid negotiations (e.g. Besada \& Kindornay, 2013; Bräutigam, 2011; Brown \& Morton, 2008; Eyben, 2013; Kim \& Lightfoot, 2011; Kindornay \& Yiagadessen, 2013; Verschaeve \& Orbie, 2016a). More specifically, literature distinguishes between two major challenges for the DAC, respectively, (i) its lack of inclusiveness, referring to the fact that only traditional donors take part in its work ${ }^{3}$ (Besada \& Kindornay, 2013; Brown \& Morton, 2008; Eyben, 2013) and (ii) the proliferation of 'new' providers of aid (e.g. BRICs, philanthropic foundations, private sector), challenging its pre-eminent status in defining donor norms and

Korea, Luxembourg, Netherlands, New Zealand, Norway, Poland, Portugal, Slovak Republic, Slovenia, Spain, Sweden, Switzerland, United States and United Kingdom.

${ }_{3}$ It has to be noted, though, that in recent years the DAC has become more inclusive by expanding its membership as well as including non-members such as the Arab donors in its work. Furthermore, the Committee 'outsourced' its work on aid effectivness to the Global Parntership for Effective Development Co-operation, motivated by the fact that the latter is a more legitimate venue for discussing these issues due to its global membership (see e.g. Verschaeve \& Orbie, 2016a).

This article is protected by copyright. All rights reserved. 
principles (Dreher, Fuchs, \& Nunnenkamp, 2013; Kim \& Lightfoot, 2011; Quadir, 2013; Zimmermann \& Smith, 2011).

The central aim of this study is to engage with the ongoing debate on the DAC's role in the changing development landscape. We wonder to what extent the European Union (EU) poses a challenge for the DAC. Indeed, while literature thus far focused on the challenges outside the DAC's membership (e.g. Eyben, 2013; Kim \& Lightfoot, 2011; Paulo \& Reisen, 2010; Zimmermann \& Smith, 2011), it overlooked the elephant in the room, namely, the EU. Indeed, for several reasons, one could expect the EU to have a detrimental impact on the DAC. Already from the time of the DAC's inception, there have been clear tensions between the EU and the DAC due to their overlapping roles and membership (Carroll \& Kellow, 2011; Mahon \& McBride, 2008). This has only become more prominent over time. First, the EU has increasingly assumed itself a coordinating role on development from the turn of the Millennium onwards. Indeed, while initially the EU was preoccupied with establishing itself as a bilateral donor alongside its members (Arts \& Dickson, 2004; Holland \& Doidge, 2012), it gradually also started to play an active role in the coordination of the development policies of its members, relying on a set of soft-integration mechanisms such as target-setting, monitoring and peer pressure (Carbone, 2008a; Delputte \& Orbie, 2014). While these efforts should not be mistaken with a transfer of power to the European level - development cooperation remains an area of shared competences between the EU level and member states - it does create a new dynamic whereby one no longer simply can discard the European level when dealing with development policies at the level of the EU member states (Delputte, Lannoo, Orbie \& Verschaeve, 2016; Holland \& Doidge, 2012). Second, the overlap in membership between the EU and DAC has significantly increased over time. While at the time of the DAC's inception in 1960 the EU already made up for 6 of the 11 members, it currently accounts for 21 of the 30 members ${ }^{4}$. Especially the accession of the Czech Republic, Poland, the Slovak Republic and Slovenia in 2013 further expanded the EU's numerical weight in the DAC.

Taking both evolutions together, one can thus expect that the EU has a substantial impact on the DAC's functioning. This observation is not new. Already in 2008 the then outgoing DAC chair

\footnotetext{
${ }^{4}$ Note that the EU has always been a full member of the DAC, and therefore in this calculation is included in the group of EU countries.
}

This article is protected by copyright. All rights reserved. 
Richard Manning pointed out that "with 15 EU Member States and the European Commission in a membership of 23, the question of what collective action takes place in Brussels and what in Paris is a live issue" (2008, p. 14). However, how this exactly plays out in practice has thus far been neglected in literature. Notable exceptions are Carbone (2007, 2013) and Keijzer (2011) which studied the High Level Forums (HLFs) in Paris, Accra and Busan and argued that EU coordination in the run up to these meeting left little political room for other DAC members and the DAC Secretariat (hereafter Development Co-operation Directorate or DCD). However, while these studies are extremely useful for understanding the EU's actorness and effectiveness at the DAC's HLFs, they do not capture the day-to-day relationship between both organizations. Indeed, the DAC's work on aid effectiveness is - or better was ${ }^{5}$ - very distinctive from the rest of its work (Eyben, 2013; Manning, 2008). For one thing, there is no EU coordination in Paris in the sense of adopting a common position before each meeting - motivated by the fact that both the EU delegation and its Member States feel such efforts would run counter the DAC's deliberative way of functioning. Rather they meet prior to each DAC committee, simply exchanging views on their respective positions (Verschaeve \& Takacs, 2013). Therefore, it remains to be seen how exactly the EU interacts and influences the DAC's decision-making, taking into account the former's emerging coordinator role and the growing overlap in membership between both institutions.

The central aim of this study is to address the above research question. By doing so, we add to the literature in several ways. Empirically, this study provides the first analysis on this topic. Indeed, neither the study of the DAC (e.g. Bräutigam, 2011; Eyben, 2013; Kim \& Lightfoot, 2011; Masujima, 2004; Ruckert, 2008), nor the literature on EU development policy (e.g. Carbone, 2007; Gänzle, Grimm, \& Makhan, 2012; Holland \& Doidge, 2012) or the EU's role in international institutions (e.g. Blavoukos \& Bourantonis, 2011; Jørgensen \& Laatikainen, 2013; Kissack, 2010) thus far paid attention to the EU-DAC relationship. Sole exceptions are two book chapters, both providing a first institutional overview of the relationship (Carroll \& Kellow, 2012; Verschaeve \& Takacs, 2013). Finally, this study also adds to the literature on international aid governance (Besada \& Kindornay, 2013; Boas \& McNeill, 2004; Woods, 2008a) as it

\footnotetext{
${ }^{5}$ Following the agreement reached in Busan (2011), the DAC turned its work on aid effectiveness over to the newly
} established Global Partnership for Effective Development Co-operation.

This article is protected by copyright. All rights reserved. 
extends our understanding of the DAC's functioning. Moreover, it provides a detailed account of the impact of regional integration processes on the existing international aid regime.

The remainder of this article is structured as follows. First, we provide a brief methodological overview in which we discuss our case selection and data collection. Then, section three constitutes the main empirical section of this study. We pay particular attention to the cases of PCD and the concessionality of ODA loans and show how the EU structure poses a structural challenge for the DAC's role in international development cooperation. The article concludes with some general reflections on the main findings of this study.

\section{Methodology}

As outlined in the introduction to this article, this study provides the first in-depth analysis of the EU-DAC relationship. More specifically, we wonder how exactly the $\mathrm{EU}^{6}$ interacts and influences the DAC's decision-making on a day-to-day basis, taking into account the former's emerging coordinator role and the growing overlap in membership between both institutions. To address this question, two topical cases have been selected, respectively, the promotion of PCD and the concessionality of ODA loans. Both cases dominated the DAC's work in recent years. Moreover, they are very distinctive from one another - both in terms of substance and role played by the EU - as such providing a comprehensive overview of the EU-DAC relationship. The data for this study were obtained through (i) 37 semi-structured expert interviews with DCD and DAC Member States' officials ${ }^{7}$, (ii) archive study and document analysis (e.g. minutes of meetings, intra-delegations' correspondence) and (iii) participatory observation ${ }^{8}$ in several meetings of the DAC during the period 2012-2013.

\footnotetext{
${ }^{6}$ As became clear in the introduction, this research focuses on both the EU - referring to the institutions (i.e. the European Commission) - and the EU member states. In what follows, we will discuss both separatly, however, it should be pointed out it is often very hard - if not impossible - to distinguish between both levels as EU member states often succeed in uploading their preferences to the European level.

${ }^{7}$ As various officials were only willing to share their views on the condition of absolute anonymity, interviews are indicated by a general reference only.

${ }^{8}$ We are grateful to the Belgian delegation to the OECD, in particular to Dr. Martinus Desmet and Mr. Lieven De La Marche.
}

This article is protected by copyright. All rights reserved. 


\section{Results}

\subsection{Policy coherence for development}

Our first case deals with the EU's role in the prioritization of PCD in the DAC. The principle of PCD refers to the general idea that non-aid policies of donor countries have an impact on the developing world and therefore should take into account the latter's needs and interests (Ashoff, 2005). The principle was already introduced by the DAC in 1991 (OECD/DAC, 1991), however, it only became one of its key priorities in recent years. Indeed, while during the 1990s and early 2000s, the DAC's main concern was to avoid policy incoherence in its member's development policies - most notably through its peer reviews (Manning, 2008; OECD/DAC, 2006; Verschaeve, Delputte \& Orbie, 2016), it has become more ambitious in recent years as it now also aims to a achieve a better understanding of the potential positive synergies between development cooperation and other policy areas (OECD, 2013; OECD/DAC, 2013d). This is most clearly reflected in the DAC's new mandate according to which the promotion of PCD is a key priority (OECD/DAC, 2011). In this section, we pay particular attention to the EU's pivotal role $^{9}$ in prioritizing PCD in the DAC. We argue that while the EU's efforts to prioritize PCD may seem positive for the DAC and the development community at large, they also had a negative impact on the Committee as they eroded its internal legitimacy.

The underlying story goes back to 2007. At that time, the DAC initiated its 'strategic reflection exercise, referring to the process it undertook to reevaluate its role, structure, functioning and composition in the changing aid landscape (OECD/DAC, 2008, 2009). This effort came at the initiative of the DCD and served as a response to the mounting criticism the DAC had faced in the aftermath of the HLFs in Paris and Accra. The aim of the reflection exercise was to adopt a set of policy recommendations, which in turn could be used as a stepping stone to revise the DAC's mandate for the first time ever, as such showing the international community its willingness to adapt to the changing development landscape (OECD/DAC, 2009; Verschaeve, 2012).

To facilitate the entire process, the DCD set up a number of task forces, each focusing on a particular topic or question. Initially, the plan was to establish two of them, respectively, one

\footnotetext{
${ }^{9}$ At a more general level, it should be noted that a number of other dynamics also account for the rise of PCD on the western donors' aid agenda, ranging from the changing development landscape to securitization trends or an emerging beyond aid thinking (e.g. Prontera, 2014; Thede, 2013).
}

This article is protected by copyright. All rights reserved. 
dealing with the role of the DAC in global aid governance and one focusing on the Committee's functioning and composition. By doing so, the DCD aimed to tackle questions such as: "What role has the DAC in the global aid effectiveness regime?", or "Should the DAC reconsidered its composition?" (OECD/DAC, 2009, 2010b). Ultimately, however, the idea was launched to establish a third task force as well, focusing on the promotion of PCD and Global Public Goods (GPGs). This came at the suggestion of the EU delegation, the Netherlands and Finland who felt it was necessary to focus on these issues in the light of the changing development landscape.

While being well intended, this proposal quickly initiated a heated debate in the DAC, dividing the Committee into two groups, namely EU and non-EU countries. Starting with the latter group, all influential non-EU countries (i.e. Australia, Canada, Japan, Norway, US, Switzerland) opposed the proposal. This was also the case for most DCD officials. Both rejected the idea for two reasons. First, and in line with the Strategic Reflection Exercise's underlying rationale, it was argued that the DAC needed to focus all its attention on its most important - read existential - questions (interviews, 4-5,17-18,23-24,32). Second, several of these countries (i.e. Australia, Canada, Japan, US) were reluctant to put too more emphasis on the promotion of PCD, while others (i.e. Norway, Switzerland) did support the idea, though, argued that addressing the potential positive synergies between different policy areas fell beyond the scope of the DAC's work and therefore should be left to the OECD. The latter was also the line taken by most DCD officials (interviews, 12,17,23-27) as they $\mathrm{did}$ not had "[...] the expertise and resources to successfully drive the PCD agenda, especially compared to the OECD's general secretariat" (interview 27).

On the other side of the spectrum, virtually all EU donors supported the idea to establish a third task force on PCD and GPGs. What is remarkable, however, is that this outcome cannot be explained by prior EU coordination on the issue. Indeed, the prioritization of PCD was selfevident for most EU members of the DAC (i.e. Austria, Belgium, Ireland, France, Germany, Spain, Sweden, UK), whereas others (i.e. Greece, Italy, Poland, Portugal) felt politically constrained to support the proposal (interviews 1,8,17-19,28-29). This outcome can be explained by the engagements on PCD that were previously made at the European level. More specifically, from the turn of the Millennium onwards, the European Commission and some of its Member States (i.e. Denmark, the Netherlands, and Sweden) had systematically promoted the principle in

This article is protected by copyright. All rights reserved. 
Brussels (Carbone, 2008b; Hoebink, 2005). Most notable in this regard is the European Consensus on Development (2005) which makes explicit reference to the promotion of PCD, granting the Commission a key role in monitoring progress on this topic within both its own policies as well as those of its member states ${ }^{10}$ (Carbone, 2008b). As such, most EU countries had already become engaged with the promotion of PCD by the time of the DAC initiated it strategic reflection exercise, explaining why they supported the idea of establishing this third task force. Moreover, those EU countries that did not favor the idea (i.e. Greece, Italy, Poland, Portugal) found themselves rhetorically entrapped because of the collective commitments they had previously made at the EU level. This was clearly pointed out by several interviewees who argued that in the absence of the EU structure, these countries would almost certainly have sided with the US, Canada or Japan (interviews, 2-4,11,13-14,32).

Ultimately, following several rounds of heated debate, the DAC reached in 2008 an agreement on this topic. More specifically, the former group gave in on the issue, resulting in the establishment of the third task force on PCD and GPGs. The underlying rationale is that they had come to realize that they were fighting a battle that could not be won. Not only did they feel it would be impossible to convince the large group of EU members from their argument decisions in the DAC are taken by consensus -, they also did not wanted to jeopardize the entire strategic reflection exercise over this issue (interviews, 12,23,25,28). This also explains why further down the process, it was never considered to be an option to only take those policy recommendations that originated from the first two task forces into account while writing the new DAC mandate (interviews, 24,27). Therefore, and as outlined in the beginning of this section, the DAC's new mandate that was adopted in 2011 pays much attention to the promotion of PCD. More specifically, it puts forward the principle as one of its key priorities, one that needs to be achieved in close collaboration with the rest of the OECD (OECD/DAC, 2011).

At first sight, the above outcome may seem beneficial for the DAC, knowing that the Committee had undertaken several failed attempts in the past to prioritize PCD (Carbone, 2008b; Forster \& Stokke, 1999). However, this is only half of the story. While the DAC indeed obtained a much stronger mandate on PCD, it came at a high cost. More specifically, the way in which PCD made

\footnotetext{
${ }^{10}$ This gave ground to a series of biannual follow-up reports on PCD, issued by the European Commission from 2007 onwards.
}

This article is protected by copyright. All rights reserved. 
its way up the agenda of the DAC was detrimental for its internal legitimacy ${ }^{11}$. While traditionally, the DAC has always derived a great deal of its internal legitimacy from the fact that its offers its members an unique forum to deliberate on what collective actions to taken (Manning, 2008; Masujima, 2004; Verschaeve \& Orbie, 2016a), this case illustrates how the EU structure is eroding this decision-making culture. More specifically, due to the strong overlap in membership, internal EU dynamics constitute a magnifying impact on the DAC. As such, nonEU members of the DAC are increasingly confronted with a reality in which they no longer have an equal chance to weigh upon the DAC's decision-making. Especially, when clear and/or strong collective targets have been set in Brussels on a particular issue - as was the case with PCD -, it is difficult and perhaps even impossible for the non-EU members (but also the DCD) to prevent its rise on the political agenda of the DAC (interviews, 3,7,12,23-27). Or as put neatly by one of the interviewees: "What happens in Brussels does not stay in Brussels" (interview 11).

This dynamic poses a structural challenge for the DAC's internal legitimacy in two important ways. First, non-EU DAC members risk being confronted with a political agenda that no longer reflects their own interests. In this case, for example, countries such as the US, Japan, Canada or Australia had - and still have ${ }^{12}$ - a lukewarm attitude towards the promotion of PCD. However, due to the ambitious provisions on PCD in the DAC's mandate, they are currently subjected to several initiatives taken by the OECD and DAC on this topic. Second, some EU countries have come to depreciate the DAC because of the above-described dynamic. More specifically, due to the often strong overlap in agenda between the EU and the DAC, questions frequently arise about the latter's added value in international development $(6,16,36)$. This is most visible in the case of Austria, as the country no longer has a permanent representative to the DAC ${ }^{13}$, motivated by the fact that it is cheaper and more efficient to shift their development efforts towards Brussels (interview, 10,33).

\subsection{Concessionality of ODA loans}

This second case focuses on the issue of concessional loans, which basically is the question of how to count loans as ODA? As outlined in the introduction to this article, one of the DAC's

\footnotetext{
${ }^{11}$ Here defined as the popular support the DAC receives from its members.

${ }^{12}$ This was outlined by several interviewees and also reflects from the fact that they abstain from most PCD related events/meetings.

${ }^{13}$ Instead, the Austrian DAC delegate flies in for every meeting of the Committee.
}

This article is protected by copyright. All rights reserved. 
main responsibilities is the monitoring of aid flows. For this purpose, it adopted already in 1969 the definition of ODA ${ }^{14}$ (Hynes \& Scott, 2013). Importantly, while most official aid is provided through grants, loans can count as ODA as well. More specifically, the face value of a loan is ODA-eligible if the loan contains a grant element of at least $25 \%$. This is calculated based on a reference rate of $10 \%$, a convention that was adopted in $1972^{15}$ (Manning, 2008). However, in today's world of historic low interest rates, this reference rate is no longer an appropriate proxy for measuring donor efforts. As such, loans easily contain a grant element $25 \%$ and even profitmaking loans can pass the concessionality test (i.e. donors raise funds on the private capital market at a low rate and re-lent it at harder terms, though, below 10\%). This created a clear tension between the spirit of the ODA definition - i.e. aid flows need to involve a donor effort and the letter of the ODA definition - i.e. loans are concessional if they contain a grant element of 25\% (Colin, 2014; Roodman, 2014). In this section, we focus on the EU's role in this debate. More specifically, we elaborate on the Union's practice of reporting profit-making loans as ODA and argue that the existence of the EU structure hampered the DAC from tackling this issue in an effective way.

The issue of concessionality emerged in parallel with the financial crisis of 2008. Due to the fact that interest rated had fallen sharply and remained at historic lows, a number of DAC donors started to report profit-making loans as ODA. Importantly, the EU was one of them, reporting loans from the European Investment Bank (EIB). In a similar fashion, also France and Germany were adding profit-making loans to their ODA figures (Colin, 2014; Manning, 2013; Roodman, 2014). For quite some time, this went unnoticed, however, when the EU provided the DAC in 2009 more detailed information on its ODA figures of 2008 in the context of its annual reporting, DCD officials found out the practice. Confronted with this act of "creative accounting", they asked to EU to stop the reporting of profit-making loans, as they were not in line with the spirit of the ODA concept. Moreover, the DCD openly wondered to what extent the EU was actually capable of reporting the EIB's loans as ODA since "the grant element concept is not applied to the market-based lending operations of the multilateral development banks" (OECD/DAC,

\footnotetext{
${ }^{14}$ Aid flows count as ODA if they flow from official agencies to official agencies, promote economic development and are concessional in character.

${ }^{15}$ At that time, this served as a proxy for the opportunity cost of public investment required to make funds available for lending. A detailed overview on how the concessionality of loans are calculate can be found here: (OECD/DAC, 2012c).
}

This article is protected by copyright. All rights reserved. 
2013a, p. 2). Read between the lines: the EU cannot add the EIB's loans to its ODA budget due to its particular nature as a development actor (interviews, 6,9,31,34).

For understandable reasons, the latter caused hard feelings in Brussels ${ }^{16}$ and a heated discussion emerged between the EU and the DCD, both on concessionality and the Union's membership status in the DAC (European Commission, 2010; OECD/DAC, 2010c, 2012a; interviews, 67,20,32). Or to cite one DCD official: "the whole issue blew up in our face" (interview 31). In 2010, the issue further escalated when the DCD found out that also Germany and France had been reporting similar loans (interview 28). Initially, DCD officials tried to solve the issue bilaterally with the EU, France and Germany. However, after several failed attempts, the discussion was broadened to all DAC members. Given that none of the other DAC members had been reporting similar loans, the DCD hoped to finally solve the issue and come up with a new and clearer definition of "concessional in character" (Colin, 2014; OECD/DAC, 2013c; interviews 28-29,31-32,34).

This turned out to be much harder than initially expected. While there was indeed a large majority of DAC members - both EU and non-EU donors - that condemned the practice and were in favor of lowering the discount rate of $10 \%$ towards the prevailing market rates, the EU, France and Germany were not willing to give in on the issue (interviews, 1,7-8,22-26). Their argument was twofold, namely, (i) that they had not violated the ODA definition and (ii) that they promoted development through these loans as the latter were offered at lower rates than the ones these countries would obtain at private capital markets. Moreover, the EU also pointed out that these loans targeted middle-income countries, in particular projects that were profit-making in the long-term (OECD/DAC, 2010a, 2010c; interviews 6,13,29,31,34).

Most of the remaining DAC members did not agree with these arguments. On the contrary, in their views, the reporting of profit-making loans undermined the credibility of the ODA concept. Moreover, it was argued that the DAC urgently needed to tackle the concessionality issue to prevent other DAC members from being tempted to start including similar types of loans to their ODA figures. Especially at a time of austerity and declining ODA budgets, this could create a

\footnotetext{
${ }^{16}$ The EU has always been extremely sensitive about being threatened equal to all other members of the DAC (see e.g. Verschaeve \& Orbie, 2016b).
}

This article is protected by copyright. All rights reserved. 
dangerous competition among donors to artificially inflate ${ }^{17}$ their aid figures towards $0,7 \%$, which in turn would easily undo all previous efforts of debt forgiveness (interviews, 9,23,28,3536).

By 2012, still no agreement had been reached on the issue. Therefore, in an attempt to break this deadlock, the DAC scheduled the concessionality issue at its annual High-Level Meeting (HLM) in December. The outcome of the HLM was that DAC members agreed to disagree at the latest until $2015^{18}$. By that time, a larger reform of the ODA definition was scheduled in which adopting a clear and quantitative measure of concessionality was listed as one of the key priorities. Other issues that needed to be tackled were questions related to whether or not to maintain student scholarships, in-donor refugee costs and debt relief within the scope of the ODA definition. Moreover, the DAC also aimed to reconsider the overall relevance of the ODA concept, focusing on general questions as there are: "Is the ODA concept outdated?", "Should the ODA definition - or a new concept - be broadened towards climate change, or development efforts made by the private sector?" (OECD/DAC, 2013b; interviews, 16-18). In sum, the DAC HLM outlined an ambitious and holistic ODA agenda and the idea was that a solution to the concessionality issue would be a part of a larger package deal (interviews, 31-32).

The above strategy, however, did not played out according to plan. On the contrary, the concessionality issue continued to dominate most of the DAC's work on ODA in the subsequent years as the EU, France and Germany continued to be unwilling to change their stance on the issue (OECD/DAC, 2012b, 2012c, 2013c, interviews, 21,36). It was only in the second-half of 2014 that a compromise was reached which envisaged a significant lowering of the reference rate of $10 \%$ (Barder \& Klasen, 2014). This agreement was further refined by December 2014 when the DAC outlined the contours of a larger ODA reform. More specifically, the DAC agreed to

\footnotetext{
${ }^{17}$ To some extent this is a false argument as repayments of loans are counted as negative ODA. Traditionally, however, repayments only start after 3 years, creating a situation in which a donor counts the face value of a loan to its ODA budget in year one, while deducting the repayments from its aid budget from year four onwards. The potential danger of this situation - and the argument that was made by the DCD and the first group of countries - is that donors thus could continue providing new loans in order to artificially level these negative repayments out. As a result, there is no fall in ODA budgets if a donor provides in year four a new loan with a face value higher than the repayments it receives that year, which obviously provides an incentive to donors to increasingly distribute loans to developing countries.

${ }^{18}$ This deal gave ground to much criticism. Most notable was an opinion piece of former DAC chair Richard Manning in the Financial Times in which he openly states that the DAC allows 'finance ministries to get away with murder as they seek to massage reported aid upwards at minimum costs. If the OECD cannot do a professional job on this, the UN should take over the reporting for international aid flows' (Manning, 2013).
}

This article is protected by copyright. All rights reserved. 
apply from 2018 onwards the IMF's variable discount rate - at present 5\% - and then apply an adjustment factor - varying from $1 \%$ to $4 \%$ - depending on the income group of the borrowing country. In layman's terms: the need for concessionality reduces as countries become richer (OECD/DAC, 2014). The ODA agreement also outlines a number of measures to increase official aid towards the LDCs, and it mandates the DAC to create a new measure called Total Official Support for Sustainable Development (TOSD). This measure will complement ODA and will cover resource flows to developing countries and multilateral institutions in support of sustainable development (OECD/DAC, 2014, interview 37).

Of particular relevance for this paper is, however, the fact that it took the DAC more than five years to reach the above agreement. While from a historical point of view, one could rightly argue that revisions of the ODA definition have always proven to be lengthy and difficult processes (e.g. Führer, 1996; Hynes \& Scott, 2013), our findings indicate that the EU structure added to this, hampering the DAC from tackling the concessionality issue in an effective way. This was the case for several reasons. First, several EU members refrained from taking a clear/strong position on the issue as they did not wanted to offend the EU delegation. Indeed, while from the very start virtually all EU members were against the reporting of profit-making loans, several of them refrained from actively defending this position. For example, the Czech Republic, Poland, the Slovak Republic and Slovenia largely kept silent during the discussions on this topic for the simple reason that the EU had been the main advocate of their (ongoing) accession to the DAC (interviews 11,19,22,33,36). Also other EU countries found themselves in a difficult position to criticize the EU since they distribute a large share of their ODA through the Unions budget (e.g. Austria, Greece, Italy) and/or simply did not wanted to undermine their relations with Brussels, especially in the light of the ongoing Eurozone crisis ${ }^{19}$ (interviews, 2,10,13-14). In sum, the EU's structure - unintentionally (!) - poses a structural problem for the DAC's functioning as it constrains several EU members to actively take part in the Committee's deliberative decision-making.

Second, the EU complicated the DCD's efforts to reach a compromise by trying to bypass the DAC and adopt a common European position on concessionality in Brussels. Indeed, in 2012,

\footnotetext{
${ }^{19}$ Illustrative for this is also the fact that several of these countries went behind the EU's back to the DCD, asking the latter not to given in on the concessionality issue (interviews 33-34).
}

This article is protected by copyright. All rights reserved. 
the EU - supported by France and Germany - organized a meeting on concessionality in Brussels. This meeting was organized on short notice and the idea was that most delegations would be insufficiently prepared to fully capture the importance of a seemingly technical issue. As such, the EU hoped to adopt a common European position in support of its own view on concessionality, which then afterwards would become incontournable for the DAC (interviews 21,33-35). Ultimately, such an agreement was not reached as most EU countries did not wanted to bypass the DAC (interview 31,33). However, and essential to this study, it does illustrate the structural threat caused by the EU level. Indeed, the Brussels' level offers both the European Commission and its member states an alternative venue to discuss issues that are at the core of the DAC's work. Moreover, when such meetings take place, the DAC is forced to shift its attention towards Brussels, as was the case here. Obviously, the DCD is well aware of this imminent threat ${ }^{20}$, explaining why it invests much time and efforts in following up on Brussels. Since 2005 - not surprisingly the year in which the European Consensus was adopted - it holds, for example, regular six-monthly meetings with the Commission. The downside of this, however, is that these efforts are time consuming and further add to the image of the DAC being a “European club” (interviews 2-3,7,12,23,36).

\section{Discussion and conclusion}

The central aim of this study was to assess to what extent the EU poses a challenge for the DAC's role in international development. While literature thus far focused on the challenges outside its membership (i.e. its lack of inclusiveness and the re-emergence of new providers of aid), this study wondered to what extent scholars did not overlook the elephant in the room, namely the EU. Indeed, literature thus far paid no attention to the EU-DAC relationship. Nonetheless, there has been a growing overlap in membership between both organizations currently the EU accounts for almost two third of the DAC's members. Furthermore, the EU evolved in recent years from a purely bilateral donor alongside its members to an actor that also increasingly aspires itself a coordinating role over the development policies of its member states.

\footnotetext{
${ }^{20}$ Ironically, though, the DAC does advocates in favor of strengthening the EU's federating role in its peer reviews (OECD/DAC, 2002, 2007, 2012d) as it makes more sense from an aid effectiveness point of view to strengthen the EU coherence and coordination. Again, this illustrates the structural dimension to this problem.
}

This article is protected by copyright. All rights reserved. 
The main finding of this study is that the EU indeed poses a major challenge for the DAC's role in international development. While the DAC has always been an effective and deliberative functioning organization (e.g. Manning, 2008; Verschaeve \& Orbie, 2016), this study shows that the EU is increasingly hampering this decision-making culture. More specifically, according to our analysis, the problem is not so much the growing overlap in membership between the EU and the DAC - off course this does not help the situation (see infra) - but rather the EU's changing nature as a development actor, turning itself from a bilateral donor alongside its members into an actor which also assumes itself a coordinating role over the development policies of its members. Furthermore, our findings illustrate that the very nature of the EU structure - regardless of collective actions at the European level - influences the DAC's decision-making.

The most prominent problem for the DAC is the EU's changing nature as a development actor. This hampers its decision-making in two important ways. First, collective actions that are taken at the European level are a constraining factor for its functioning. This is most clearly reflected in the PCD case. Indeed, because of the already existing strong and collective European targets on policy coherence, EU member states felt constrained - both in a positive and negative way to support the EU's idea of prioritizing PCD during the DAC's strategic reflection exercise. This made it virtually impossible for the other DAC members to prevent the rise of PCD on the DAC's agenda. Second, the EU's changing nature as a development actor offers both the Commission and the EU member states an alternative venue to discuss issues that are at the core of the DAC's work. This is exactly what happened in the concessionality case, illustrated by the fact that the EU, France and Germany tried to bypass the DAC in Brussels. While at present, there still is general unwillingness among most EU DAC member states to use this sidetrack, one cannot ignore the fact that the EU itself has increasingly come to prioritize the streamlining of the Union's external actions in recent years. Clear examples are the creation of the EEAS in 2011 or the dominant discourse on promoting coherence within the Brussels bubble, both decreasing the costs to bypass the DAC.

Apart from the EU's changing nature as a development actor, our findings also reveal that the EU structure by itself is detrimental for the DAC's functioning. As reflects from the concessionality case, the EU structure had a constraining effect on several of its members states,

This article is protected by copyright. All rights reserved. 
as is witnessed by the fact that several of them refrained from condemning the EU's reporting of profit-making loans as ODA. Indeed, member states refused to openly scrutinize the EU on this issue for various reasons, ranging from strategic motives to the fact that they distribute a larger share of their ODA through the Union's budget.

Importantly, the impact of the growing overlap in membership between the EU and the DAC is less relevant than initially expected. Essentially, it is an important variable for understanding the EU's impact on the DAC, though, only in relation to the above described dynamics. This clearly reflects from the PCD case as the collective EU commitments on PCD constituted a magnifying effect on the DAC due to the large overlap in membership between both organizations.

Taking the above elements together, it can thus be concluded that the EU's impact on the DAC is substantial, to say the least. While the DAC has always derived its internal legitimacy from its deliberative and effective functioning, one cannot ignore the fact that the EU is eroding the Committee's legitimacy basis. Indeed, the fact that the EU structure functions - often unintentionally (!) - as a straightjacket for (some) of its members inevitable raises questions about the Committees added-value in international development, both among EU and non-EU members of the DAC. Moreover, while the DAC has struggled with the image of being a "European club" for most of its existence, this perception has only been further enforced by the EU's changing nature as a development actor and the DCD's reaction to this new political reality.

In sum, this study sheds a rather pessimistic view on the DAC's future role in international development. While literature thus far already identified two major external challenges for the DAC's role in international development (i.e. its lack of inclusiveness and the emergence of new providers of aid), we add a third one to the list. Indeed, our findings clearly indicate that the EU is the elephant in the room that nobody is talking about. Moreover, unlike in the case of the first two challenges, there is no easy/clear fix to the challenge posed by the EU - assuming there is a fix at all. While the DAC could try to further expand and diversify its membership as an attempt to level out the magnifying effect constituted by the large overlap in membership between both institutions, its future lies to a large degree in the hands of the EU and its member states. Therefore, the lessons that can be drawn from this study is that it is up to the EU and its member states to be extremely reflexive about their strong position in the DAC, whereas the DCD should

This article is protected by copyright. All rights reserved. 
continue to work closely together with all its members, illustrating the DAC's added value. Otherwise, the international community risks losing an unique and important institution in the fight against global poverty.

\section{References}

Arts, K., \& Dickson, A. (Eds.). (2004). EU development cooperation. From model to symbol. Manchester: University Press.

Ashoff, G. (2005). 'Enhancing policy coherence for development: justification, recognition and approaches to achievements', German Development Institute Studies (11).

Barder, O., \& Klasen, S. (2014). 'Ending the exaggeration of aid: a modest proposal', Center for Global Development, Blogpost.

Besada, H., \& Kindornay, S. (2013). Multilateral Development Cooperation in a Changing Global Order. Basingstoke: Palgrave Macmillan.

Blavoukos, S., \& Bourantonis, D. (Eds.). (2011). The EU Presence in International Organizations. London: Routledge.

Boas, M., \& McNeill, D. (Eds.). (2004). Global institutions and development: framing the world? London: Routledge.

Bräutigam, D. (2011). 'Aid 'With Chinese Characteristics': Chinese Foreign Aid and Development Finance Meet the OECD-DAC Aid Regime', Journal of International Development, 23(5), 752-764.

Brown, S., \& Morton, B. (2008). 'Reforming aid and development cooperation: Accra, Doha and beyond', The North-Sout Institute: policy note.

Carbone, M. (2007). The European Union and International Development : The politics of foreign aid. London: Routledge.

Carbone, M. (2008a). 'Introduction: The New Season of EU Development Policy', Perspectives on European Politics and Society, 9(2), 111-113.

Carbone, M. (2008b). 'Mission Impossible: the European Union and Policy Coherence for Develoment', Journal of European Integration, 30(3), 323-342.

Carbone, M. (2013). 'Between EU actorness and aid effectiveness: The logics of EU aid to SubSaharan Africa', International Relations, 27(3), 341-355.

This article is protected by copyright. All rights reserved. 
Carroll, P., \& Kellow, A. (2011). The OECD. A study of organisational adaptation. Cheltenham: Edward Elgar Publishing Limited.

Carroll, P., \& Kellow, A. (2012). The OECD. In K. E. Jorgensen \& K. V. Laatikainen (Eds.), Routledge handbook on the European Union and international institutions. London: Routledge.

Colin, S. (2014). A matter of high interest: Assessing how loans are reported as development aid: EURODAD.

Delputte, S., Orbie, J., Lannoo, S. \& Verschaeve, J. (2016). 'Europeanisation of Aid Budgets: Nothing is as it seems', European Politics and Society, 17(1), pp. 74-89.

Delputte, S. \& Orbie, J. (2014). 'The EU and donor coordination on the ground: perspectives from Tanzania and Zambia', European Journal of Development Research, 26(5), pp. 676-691.

Dreher, A., Fuchs, A., \& Nunnenkamp, P. (2013). 'New Donors', International Interactions, $39(3), 402-415$.

European Commission. (2010). Email communication between Mr. Richelle (directeor Aidco) and Ms. Riegler (chair WP-STAT). .

Eyben, R. (2013). 'Struggles in Paris: The DAC and the Purposes of Development Aid', European Journal of Development Research, 25(1), 78-91.

Forster, J., \& Stokke, O. (1999). Policy coherence in development co-operation. Abingdon: Frank Cass.

Führer, H. (1996). The story of Official Development Assistance: a history of the development assistance committee adn the development co-operation directorate in dates, names and figures. Paris: OECD.

Gänzle, S., Grimm, S., \& Makhan, D. (Eds.). (2012). The European Union and Global Development: An 'Enlightened Superpower' in the Making? Basingstoke: Palgrave Macmillan.

Hoebink, P. (2005). The Treaty of Maastricht and Europe's development co-operation. Amsterdam: Aksant Academic Publishers.

Holland, M., \& Doidge, M. (2012). Development Policy of the European Union. Basingstoke: Palgrave Macmillan.

This article is protected by copyright. All rights reserved. 
Hynes, W., \& Scott, S. (2013). 'The evolution of Official Development Assistance: Achievements, Criticisms and a Way Forward', OECD Development Co-operation Working Papers, 12.

Jørgensen, K. E., \& Laatikainen, K. V. (Eds.). (2013). Routledge Handbook on the European Union and International Institutions. London: Routledge.

Keijzer, N. (2011). 'Offense is the best defense? The EU's past and future engagement in promoting effective development cooperation: ideas for Busan', ECDPM Briefing Note, 30 .

Kim, S., \& Lightfoot, S. (2011). 'Does ‘DAC-Ability’ Really Matter? The emergence of nonDAC Donors: Introduction to Policy Arena', Journal of International Development, 23(5), 711-721.

Kindornay, S., \& Yiagadessen, S. (2013). Establishing a Legitimate Development Co-operation Architecture in the Post-Busan Era. In H. Besada \& S. Kindornay (Eds.), Multilateral Development Cooperation in a changing global order: Palgrave Mac Millan.

Kissack, R. (2010). Pursuing effective multilateralism. The European Union, international organisations and the politics of decision making. Basingstoke: Palgrave Macmillan.

Kragelund, P. (2011). 'Back to BASICs? The Rejuvination of Non-traditional Donor's Development Cooperation with Africa', Development and Change, 42(2), 585-607.

Mahon, R., \& McBride, S. (Eds.). (2008). The OECD and Transnational Governance. Toronto: UBC Press.

Manning, R. (2008). 'The DAC as a Central Actor in Development Policy Issues: Exeperiences over the Past Four Years', GDI/DIE Discussion paper (Vol. 7).

Manning, R. (2013, 9 April 2013). OECD is ignoring its definition of overseas aid, The Financial Times.

Masujima, K. (2004). Good governance and the Development Assistance Committee: ideas and organizational constraint. In M. Boas \& D. McNeill (Eds.), Global institutions and devleopment: framing the world? London: Routledge.

McEwan, C., \& Mawdsley, E. (2012). 'Trilateral development cooperation: Power and Politics in Emerging Aid Relationships', Development and Change, 43: 1185-1209.

OECD. (2013). Better policies for Development: In focus 2013: Policy Coherence for Development and Global Food Security. Paris: OECD Publishing.

This article is protected by copyright. All rights reserved. 
OECD/DAC. (1991). DCD/DAC(91)17: Development Co-operation and the Challenge of Policy Coherence in the New International Context. Paris.

OECD/DAC. (2002). Peer Review of the Development Co-operation Policies and Programmes of the European Community. Paris.

OECD/DAC. (2006). DAC in Dates: the history of the OECD's Development Assistance Committee. Paris: OECD publishing.

OECD/DAC. (2007). European Community Peer Review. Paris.

OECD/DAC. (2008). DCD(2008)27/REV1: Strategic Reflection Excercise: View from former DAC Chairs. Paris.

OECD/DAC. (2009). DCD/DAC(2009)23/Final: DAC Reflection Excercise.

OECD/DAC. (2010a). DCD/DAC(2010)40/REV1: DAC statistical reporting directives.

OECD/DAC. (2010b). DCD/DAC/RD(2010)2/RD3.

OECD/DAC. (2010c). Email from DCD (Mr. Jon Lomoy) to European Commission (Mr. Koos Richelle).

OECD/DAC. (2011). DCD/DAC(2010)34/Final: DAC Mandate 2011-2015.

OECD/DAC. (2012a). DCD/DAC(2012)22: Statistical Reporting Issues.

OECD/DAC. (2012b). DCD/DAC/STAT(2012)17 - Results of the Survey of approaches to determining concessionality of loans.

OECD/DAC. (2012c). DCD/DAC/STAT(2012)18 - Explanation of concepts used in concessionality and grant element calculations

OECD/DAC. (2012d). European Union Peer Review. Paris.

OECD/DAC. (2013a). DCD/DAC(2013)2: Loan concessionality in DAC statistics.

OECD/DAC. (2013b). DCD/DAC(2013)33 - Revisiting the ODA Concept.

OECD/DAC. (2013c). DCD/DAC/STAT(2013)11 - Chronology of DAC Discussions on Concessionality in Chararcter

OECD/DAC. (2013d). A Toolkit of Policy Options to Support Inclusive Green Growth. Paris: OECD.

OECD/DAC. (2014). DAC High Level Meeting: Final Communiqué

Paulo, S., \& Reisen, H. (2010). 'Eastern Donors and Western Soft Law: Towards a DAC Donor Peer Review of China and India?', Development Policy Review, 28(5), 535-552.

This article is protected by copyright. All rights reserved. 
Prontera, A. (2014). 'Subsystem politics and policy coherence in development cooperation: Evidence from four EU Member States', Comparative European Politics, 1-21.

Quadir, F. (2013). 'Rising Donors and the New Narrative of 'South-South' Cooperation: what prospects for changing the landscape of development assistance programmes?', Third World Quarterly, 34(2).

Roodman, D. (2014). 'Straightening the Measuring Stick: A 14-Point Plan for Reforming the Definition of Official Development Assistance (ODA)', CGD Working Paper, 44.

Ruckert, A. (2008). Making Neo-Gramscian sense of the Development Assistance Commitee. In R. Mahon \& S. McBride (Eds.), The OECD and Transnational Governance. Vancouver: UBC Press.

Thede, N. (2013). 'Policy Coherence for Development and Securisation: competing paradigms or stablising North-South hierarchies?', Third World Quarterly, 34(5), 784-799.

Verschaeve, J., \& Orbie, J. (2016a). 'The DAC is dead, long live the DCF? A comparative analysis of the OECD's Development Assistance Committee and the UN's Development Co-operaiton Forum', European Journal of Development Research.

Verschaeve, J., \& Orbie, J. (2016b). 'Once a member, always a member? Assessing the importance of time in the relationship between the European Union and the Development Assistance Committee', Cambridge Review of International Affairs.

Verschaeve, J., Delputte, S. \& Orbie, J. (2016). 'The rise of policy coherence for development: a multi-causal approach', European Journal of Development Research, 28(1), 44-61.

Verschaeve, J., \& Takacs, T. (2013). The EU's international identity: the curious case of the OECD. In H. Dewaele \& J.-J. Kuipers (Eds.), The emergence of the European Union's international identity. Views from the global arena. Leiden: Martinus Nijhoff Publishers.

Verschaeve, J. (2012). 'Naar een nieuw forum voor ontwikkelingssamenwerking: het UN-DCF als opvolger van het OECD-DAC?', Wereldbeeld, 36(162).

Woods, N. (2008a). Governing the global economy: . New York: International Peace Institute.

Woods, N. (2008b). 'Whose aid? Whose influence? China, emerging donors and the silent revolution in development assistance', International Affairs, 84(6), 1205-1221.

Zimmermann, F., \& Smith, K. (2011). 'More Actors, More Money, More Ideas for International Development Co-operation', Journal of International Development, 23(5), 722-738.

This article is protected by copyright. All rights reserved. 


\section{Interviews}

MS= Member State

1: MS official, 16/01/2012, Paris

2: DAC official, 17/01/2012, Paris

3: DAC official, 19/01/2013, Paris

4: ex-DAC official, 19/02/2012, Skype

5: MS official, 20/02/2012, Skype

6: MS official, 28/03/2012, Brussels

7: DAC official, 07/05/2012, Brussels

8: MS official, 11/06/2012, Paris

9: DAC official, 11/06/2012, Paris

10: MS official, 11/06/2012, Paris

11: MS official, 11/06/2012, Paris

12: MS official, 11/06/2012, Paris

13: MS official, 12/06/2012, Paris

14: MS official, 12/06/2012, Paris

15: MS official, 13/06/2012, Paris

16: MS official, 04/12/2012, London

17: DAC official, 05/12/2012, London

18: MS official, 06/12/2012, London

19: MS official, 06/12/2012, London

This article is protected by copyright. All rights reserved. 
20: ex-MS official, OECD official, 06/12/2012, London

21: MS official, 17/10/2013, Paris

22: DAC official, 17/10/2013, Skype

23: MS official, 22/10/2013, Paris

24: MS official, 22/10/2013, Paris

25: MS official, 22/10/2013, Paris

26: MS official, 22/10/2013, Paris

27: MS official, 23/10/2013, Paris

28: MS official, 23/10/2013, Paris

29: MS official, 28/10/2013, Paris

30: OECD official, 28/10/2013, Paris

31: DAC official, 30/10/2013, Paris

32: DAC official, 05/11/2013, Paris

33: MS official, 12/11/2013, Paris

34: MS official, 13/11/2013, Paris

35: MS official, 13/11/2013, Paris

36: DAC official, 26/11/2013, Brussels

37: DAC official, 13/12/2014, Skype

This article is protected by copyright. All rights reserved. 